\title{
Estimation and potential of palm oil empty fruit bunches based on crude palm oil forecasting in Indonesia
}

\author{
Arty Dwi Januari ${ }^{1 *}$, Suyud Warno Utomo ${ }^{1,2}$ and Haruki Agustina ${ }^{1}$ \\ ${ }^{1}$ School of Environmental Science, Universitas Indonesia, Jakarta, 10440, Indonesia \\ ${ }^{2}$ Environmental Health, Faculty of Public Health, Universitas Indonesia, Depok, 16424, Indonesia
}

\begin{abstract}
The increase of palm oil production produced waste, which has an impact on the environmental burden. Therefore, the purpose of this article is to predict the amount of palm oil empty fruit bunches produced per month in Indonesia to determine the potential of empty fruit bunches management. The predicted amount of the waste is based on crude palm oil (CPO) forecasts analysis that is processed using exponential triple smoothing. Based on the analysis, it was obtained that the amount of waste of empty fruit bunches proved to be directly proportional to the crude palm oil production. The efficiency of mill operation plays an essential role in CPO production and waste generation. However, this study has less variance on empty fruit bunches production since that quantity derived directly from $\mathrm{CPO}$ forecasting results based on fresh fruit bunches processed in the mills. Based on the estimation quantity, the management of palm oil empty fruit bunch as a raw material of fertilizer is sufficient to manage the produced empty fruit bunch. The data can be used to consider the waste palm's potential management in palm oil mills and national scope.
\end{abstract}

\section{Introduction}

The increase in the amount of organic waste caused by an increase in population, industry, and commercial increased the global environmental burden if not managed efficiently [1]. However, waste production is inevitable even if it is not desirable and has applied the reduction and deduction of waste production. So, it is imperative to change the concept of waste not as "waste" but as a "resource" that can be utilized and provide economic and social benefits, which is the concept of zero waste [2]. This concept is used in underlying this article to create. The utilization of waste-derived is broad-spectrum production strategies [3]. This approach minimizes reliance on non-renewable resources [4], provide a new source of renewable resource [5], and minimize the negative impact on the environment [6].

Globally, Indonesia is the largest palm oil-producing country. The increase in demand increased the growth of palm oil production plants in provinces in Indonesia. In 2015 - 2017, Indonesia experienced a $22.19 \%$ increase in palm oil production, and $2017-2019$ is expected

- Corresponding author: artydwi@gmail.com 
to increase production by $12.19 \%$ [7]. Also, it is expected the palm oil production will continue to increase in the following years [8]. Every year, Indonesia has a new plantation and factory establishment developed to increase production [9]. Increased production will ultimately increase the amount of solid and liquid waste produced. The resulting harmless, solid waste can be classified as a biomass residue that can be utilized to have added value $[10,11]$.

Palm fruit harvested on plantations can not be processed one hundred percent to become crude palm oil (CPO) cause by sorted process or process in palm oil mills. Palm oil fruits that are not of good quality can eventually become waste that is not utilized [12]. The palm fruit produced will also produce biomass residues such as palm shells, mesocarp, and empty fruit bunches. The percentage of that waste produced from CPO production is around $21-26 \%$ empty fruit bunches, $5-7 \%$ shell, around $27 \%$ washing water and condensate, $12-18 \%$ fiber, and $50-70 \%$ liquid waste [13-15]. Based on the predictable data from $100 \%$ bunches of the fresh fruit produced, about $38-51 \%$ of solid waste will produce from palm oil mills. $\mathrm{CPO}$ and waste production is affected by the production efficiency of the mills. Mills' efficiency production will be influenced by mills capacity, technical efficiency, labor, capital, machines, methods, and materials [16,17]. So that there are variations in the CPO and waste production for each mill. However, there is considerable biomass potential only from palm oil production without seeing other organic waste produced, such as stems, leaves, and midrib from the palm oil plantation process [15].

The restoration of palm oil waste resources in materials and energy will help meet the resources' needs and reduce environmental impacts. Previous studies have evaluated palm oil waste utilization from various aspects of the environment, such as fertilizers, mulch $[11,18]$, biofuel [19], bio-oil [20], cement [21]. Palm oil solid waste contains significant amounts of nutrients that can be utilized and used as soil conditioners [22,23]. That waste can be a promising raw material for waste conversion technology that leads to soil amendment or land application products. Those products can have a value-added using various waste management processes such as mulch making, composting techniques, anaerobic digestion, and biochar [11]. Waste products for soil amendment can be utilized for plantation land that has experienced a decreased soil quality. That decrease in soil quality is one factor of decreased palm oil fruit productivity produced mainly on smallholder land [22-24].

However, it is essential to understand the sustainability of the production of waste in the future in order to be able to plan waste reduction investment activities that will be determined. Estimating waste products resulting from a particular process and area is an essential activity for appropriate waste management action. Some studies have estimated substantial waste quantity such as palm oil and municipal solid waste $[15,25]$. Hambali and Rivai predicted the palm oil waste in annual form, and Qiao et al. was predicted the municipal solid waste using an exponential smoothing method [15,25]. Therefore, this paper tried to contribute to the estimated amount of palm oil waste utilized using the time series method. This study tries to estimate the number of empty fruit bunches produced from palm oil production monthly. Time series forecasting analysis will be carried out using the exponential triple smoothing (ETS). Time-series can be used for one indicator in the decision-making process. Different methods in the estimated series time analysis will provide predictive intervals with different widths intervals [25-27]. The selection of methods and accuracy levels are also influenced by factors such as desired accuracy, approximate context, data availability, the estimated period, and the purpose of interpretation [28]. However, this study did not optimize the time series results because this article aims to predict the empty fruit bunches quantity produced in Indonesia each month to determine the potential of solid waste management for that waste.

This study used the exponential smoothing technique to estimate the CPO production monthly from 2019 - 2023. This technique can be used to see the trend of CPO production in Indonesia for the next few years based on the previous years' production trend. Palm oil 
empty fruit bunches (POEFB) data estimation carried out using the CPO forecasting results with a comparison of fixed data at $24 \%$ of $\mathrm{CPO}$ and $21 \%$ POEFB produced in the country, which is derived directly from Fresh Fruit Bunches (FFB) processed. As mentioned above, these results' purposes are to determine the potential of empty fruit bunches based on the quantity produced. So, this paper results have fewer merits to determine the efficiency production in mills in Indonesia. However, the research results will be useful not only for the formulation and implementation of policies in the future but also for planning solid waste management and making the right decisions to manage such waste.

\section{Method}

This article was conducted by calculating the predicted amount of POEFB production every month based on CPO production from January 2016 - December 2018 in Indonesia. The CPO production in $2016-2018$ show in Table 1. The CPO production was obtained from documents of the ministry of agriculture and BPS-Statistics of Indonesia.

Table 1. CPO and POEFB production (2016 - 2018)

\begin{tabular}{|c|c|c|c|c|c|c|}
\hline \multirow{2}{*}{ Timeline } & $\begin{array}{c}\text { CPO } \\
\text { Production }\end{array}$ & $\begin{array}{c}\text { POEFB } \\
\text { Production }\end{array}$ & $\begin{array}{c}\text { CPO } \\
\text { Production }\end{array}$ & $\begin{array}{c}\text { POEFB } \\
\text { Production }\end{array}$ & $\begin{array}{c}\text { CPO } \\
\text { Production }\end{array}$ & $\begin{array}{c}\text { POEFB } \\
\text { Production }\end{array}$ \\
\cline { 2 - 7 } & \multicolumn{2}{|c|}{2016} & \multicolumn{2}{|c|}{2017} & \multicolumn{2}{c|}{2018} \\
\hline January & $2,491,640$ & $2,180,185$ & $3,013,468$ & $2,636,785$ & $2,739,359$ & $2,396,939$ \\
\hline February & $2,380,743$ & $2,083,150$ & $2,656,659$ & $2,324,577$ & $2,538,291$ & $2,221,005$ \\
\hline March & $2,418,428$ & $2,116,125$ & $2,824,745$ & $2,471,652$ & $2,819,323$ & $2,466,908$ \\
\hline April & $2,478,134$ & $2,168,367$ & $2,763,044$ & $2,417,664$ & $2,918,768$ & $2,553,922$ \\
\hline May & $2,446,816$ & $2,140,964$ & $2,810,215$ & $2,458,938$ & $3,160,048$ & $2,765,042$ \\
\hline June & $2,598,704$ & $2,273,866$ & $2,641,116$ & $2,310,977$ & $2,798,245$ & $2,448,464$ \\
\hline July & $2,376,607$ & $2,079,531$ & $3,071,001$ & $2,687,126$ & $3,499,298$ & $3,061,886$ \\
\hline August & $2,637,951$ & $2,308,207$ & $3,090,825$ & $2,704,472$ & $3,361,210$ & $2,941,059$ \\
\hline September & $3,150,772$ & $2,756,926$ & $3,282,708$ & $2,872,370$ & $3,399,437$ & $2,974,507$ \\
\hline October & $2,922,503$ & $2,557,190$ & $2,990,312$ & $2,616,523$ & $3,359,057$ & $2,939,175$ \\
\hline November & $2,818,797$ & $2,466,447$ & $2,906,872$ & $2,543,513$ & $3,123,890$ & $2,733,404$ \\
\hline December & $2,766,891$ & $2,421,030$ & $2,889,324$ & $2,528,159$ & $2,877,887$ & $2,518,151$ \\
\hline Total & $31,487,986$ & $27,551,988$ & $34,940,289$ & $30,572,753$ & $36,594,813$ & $32,020,461$ \\
\hline
\end{tabular}

The estimation of POEFB in January 2019 - December 2023 conducted used two-step analysis. First, forecasts of CPO production in January 2019 - December 2023 were analyzed using exponential triple smoothing (ETS). Forecasting analyzed was performed used an exponential smoothing algorithm function in MS Excel 2019 software where the error, trend, and seasonal parameters are additives. Plot time is used to compare estimates with line graphs with each plotted value observed against the observation time, and there is a line that connects each observation throughout the period. This study used a $95 \%$ confidence level to understand the forecast's accuracy for confidence level intervals. The data obtained from the documents are then reviewed and analyzed. The second step, data POEFB January $2016-$ December 2023, was calculated after the forecast of CPO production Jan 2019 - Dec 2023 was predicted. That calculation used static data to get the estimation of POEFB production 
in the country. That data was from $100 \%$ FFB produced $24 \% \mathrm{CPO}$ and $21 \%$ of POEFB $[13,15]$. The results show in Table 1 and Table 2.

\section{Results and discussion}

The economic activity efficiency, the degradation of the environment, and the need for renewable resources can be achieved using waste management systems. Based on data Table 1 total POEFB produce was 27,551,988 tons in 2016, 30,572,753 tons in 2017 and 32,020, 461 tons in 2018. The forecasting data from Table 1 is shown in Fig. 1 and Table 2.

Based on Fig. 1 analysis was obtained statistical parameter data. The statistical value of the Alpha parameter obtained from this model is 0.126 . The alpha parameter is a parameter of the base value. The results of this study suggest that actual data should be assumed to be stable for subtle fluctuations. The algorithms beta parameter is a trend value parameter indicating a value of 0.0010 in this model. The gamma parameter of the algorithm that is the seasonal value parameter, indicates a value of 0.0010 . Alpha, beta, and gamma value closer to 0 means that recent observations have little weight on predictions [29].

(a)

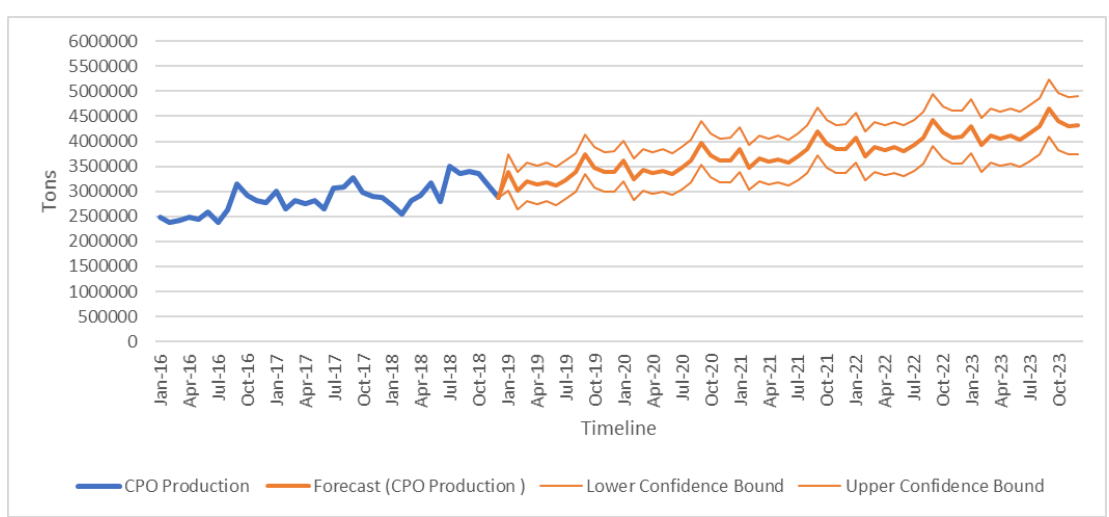

(b)

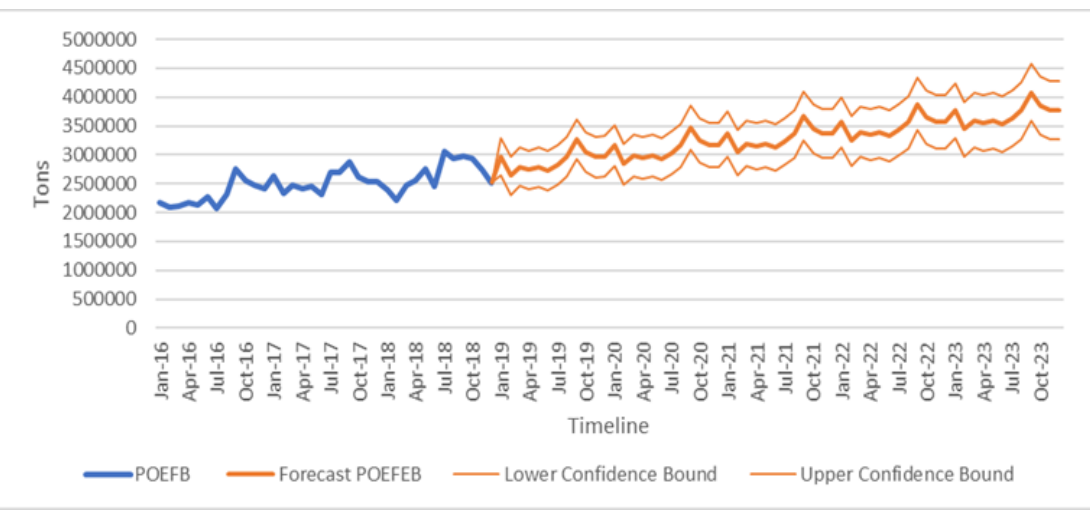

Fig. 1. Forecasts results in 2019 - 2023 (a) CPO production (b) POEFB production 
As for the forecasting error rate parameter, the smaller the error rate on the error level parameter, then the quantity forecasting results are closer to the actual quantity. The value of the parameter Mean Absolute Scaled Error (MASE) of Fig. 1 is 1.0762, and the parameter symmetric Mean Absolute Percentage Error (SMAPE) is 0.0631. The forecasting error parameter is used for model optimization comparison, especially when comparing multiple models to get the most accurate prediction results. The differences in interpretation results from optimal forecasting measurement models will guide the wisdom to choose the right forecasting model.

As mentioned above, POEFB production derived from $\mathrm{CPO}$ forecasting based on derivations of FFB processed in mills. Fig. 1 shows a similar pattern as CPO and POEFB are closely related. That production will increase each year. Simultaneously, that production in monthly-based data shows an increase and decreased quantity according to the CPO production's demand and production capability in that month. Based on that, it appears that the increase in CPO production also adds to the increase of POEFB production. The efficiency of mills operation plays an essential role in CPO and waste Production [16]. The mills' production efficiency is defending human resources, technical processes, machines, capacity, and methods $[16,17]$. However, there is less variance on POEFB production since the POEFB quantity derived directly from forecasts of CPO Production based on FFB processed in the mills. On a monthly based, the POEFB forecasting results show in Table 2.

Tabel 2. The tonnage POEFB forecasts result in Indonesia (2019 - 2023)

\begin{tabular}{|c|c|c|c|c|c|}
\hline Timeline & 2019 & 2020 & 2021 & 2022 & 2023 \\
\hline January & $2,958,537$ & $3,160,345$ & $3,362,153$ & $3,563,961$ & $3,765,769$ \\
\hline February & $2,637,197$ & $2,839,005$ & $3,040,813$ & $3,242,621$ & $3,444,429$ \\
\hline March & $2,791,973$ & $2,993,781$ & $3,195,589$ & $3,397,397$ & $3,599,205$ \\
\hline April & $2,739,123$ & $2,940,931$ & $3,142,739$ & $3,344,547$ & $3,546,355$ \\
\hline May & $2,786,140$ & $2,987,948$ & $3,189,755$ & $3,391,563$ & $3,593,371$ \\
\hline June & $2,725,293$ & $2,927,101$ & $3,128,909$ & $3,330,717$ & $3,532,525$ \\
\hline July & $2,826,851$ & $3,028,659$ & $3,230,467$ & $3,432,275$ & $3,634,083$ \\
\hline August & $2,956,856$ & $3,158,663$ & $3,360,471$ & $3,562,279$ & $3,764,087$ \\
\hline September & $3,270,116$ & $3,471,924$ & $3,673,732$ & $3,875,540$ & $4,077,348$ \\
\hline October & $3,044,858$ & $3,246,666$ & $3,448,474$ & $3,650,282$ & $3,852,089$ \\
\hline November & $2,961,646$ & $3,163,454$ & $3,365,261$ & $3,567,069$ & $3,768,877$ \\
\hline December & $2,968,718$ & $3,170,526$ & $3,372,333$ & $3,574,141$ & $3,775,949$ \\
\hline
\end{tabular}

Table 2 shows the POEFB forecasting results produced on a monthly based on 2019 2023. It is estimated that the pattern of increase in production will decrease the percentage increase in the following years until it reaches the maximum production point. The average POEFB production produced each month is approximately 2,888,942 tons/month in 2019 and 3,090,750 tons/month in 2020, which is predicted to have been produced from CPO production. In 2021 - 2023, POEFB will produce around 3,292,558 tons/month in 2021, $3,494,366$ tons/month in 2022, and 3,696,174 tons/month in 2023.

Based on Table 1 and Table 2, it can be estimated the amount of POEFB utilization from the $\mathrm{CPO}$ production. So, that amount can be managed and does not become an environmental burden, but to provide a benefit for the environment and community. It wasted the community's source of profit, nutrition recovery, and renewable energy for the environment if the palm oil empty fruits bunch manage by burned out or disposed to the disposal site. That 
methods management also provides toxicity and eutrophication effects $[11,18,30]$. Therefore, availability, continuity, and capacity of the POEFB production make that results is not waste that should be disposed of or burned but a resource that can be utilized. Besides, the utilization of that material with the implementation of zero waste principles in Indonesia can help minimize the amount of organic waste in Indonesia.

POEFB as a resource can be used as a single or mixed raw material for land application products such as fertilizer and mulch using conventional and modern techniques [11]. In addition, it can also be used as biofuel, paper, and cement materials [19-21]. As a source of raw materials for land applications, POEFB is an organic material that can reduce chemical fertilizers because it contains nutrients that need it by plantation land [23]. Applications of 30-90 tons of POEFB per hectare per year are recommended to add organic matter and improve soil fertility on palm oil plantations. Utilization of that material as fertilizer and mulch in plantation areas can increase yield from oil palm plantation land [31]. That quantity produced can be used at 1,317,023 hectares, 1,397,746 hectares, and 1,478,470 hectares of palm oil plantations in Indonesia from 2021 until 2023 with the utilization of 30 tons per hectare per year in palm oil plantation. That area utilization is the same as around $10 \%$ of palm oil plantation in Indonesia since Indonesia has around 14 million hectares of palm oil plantation in 2020 [7]. So, it can be concluded by utilizing POEFB for mulch has been sufficiently reducing the amount of solid waste from palm oil production. However, some literature has stated that its use directly into the land can contaminate the plantation land caused by the remaining oil from CPO production [18]. That can also increase disease and pests in palm oil plantation. Moreover, there are problems with transporting POEFB to the palm oil plantation $[11,32]$. Before applied to the land, that material should be processed with pyrolysis, anaerobic digestion, and composting methods. Therefore, its use as raw material for land applications can help achieve sustainable productivity of solid waste management in palm oil mills.

Data forecasts on a monthly based can be used to estimate the needs, investment, and capacity in the material's processing process. The forecasting optimization of the forecast results can utilize other methods by comparing the model's error rate. It can be used for quantities analysis requires a high degree of accuracy, such as constructing a processing facility in the factory area. Simultaneously, the trends of waste generated will be more closed and significant to the actual data if we directly used the POEFB waste generated data to make a waste forecast analysis. Besides, more data provide and updated to predicted trends will more significance and closer the trends with actual trends. However, the model used in this article has gained a better understanding of the amount of palm oil empty fruits bunch produced in Indonesia and can assist decision-makers in achieving the goal of zero waste on the sustainability of palm oil mills in Indonesia.

\section{Conclusion}

This article presents the monthly waste of palm oil empty fruit bunches conducted for five years (from 2019 to 2023) based on the forecast of CPO production even though there are limited periods of data in quantity generated and limited model capabilities. Based on analysis data, it appears that there is considerable potential, and it is sufficient to manage the palm oil empty fruits bunch use as raw materials for fertilizer. The benefit of empty fruit bunches as raw material for fertilizer production will contribute to Indonesia's organic waste management. This study was obtained that the amount of waste of empty fruit bunches proved to be directly proportional to the crude palm oil production. The efficiency of mill operation plays an important role in CPO production to reduce and increase waste generation. However, this study has less variance on POEFB production, which is derived directly from 
CPO forecasting results based on FFB processed in the mills. Then, to create a better understanding of the mills' operation's efficiency, we suggest doing further analysis based on the operation of mills production. However, more data from year to year is required to verify the model's significance and durability. Other than that, the forecasting POEFB analysis directly from the actual POEFB trend data should be done to get closer results to the actual trend of POEFB waste generated. The validity of forecasting POEFB should be done empirically in nearly future. Optimization analysis is also required by comparison with other prediction methods so that predictions data is closer to the actual amount. Quantitative estimates were obtained to allow for further study of the difference, and the correlation of period and validity of forecasting POEFB shortly should be done empirically. This results study will be useful not only for the formulation and implementation of policies in the future but also for planning solid waste management and making the right decisions to manage such waste.

\section{Acknowledgements}

This research part of riset PDUPT 2020 with the research head is Prof. Rofikoh Rokhim from the Department of Management, Faculty of Economics and Business, Universitas Indonesia (Kementerian Riset dan Teknologi/Badan Riset dan Inovasi Nasional/KEMENRISTEK/BRIN-Universitas Indonesia with contract numbers 8/E1/KP.PTNBH/2020 and 255/PKS/R/UI/2020). The authors extend sincere thanks to Dr. Rosyani and field assistants (Muhammad Abdul Aziz, Victor Rodo Artha Marpaung) as magister students of Environmental Science and Agribusiness of University of Jambi

\section{References}

1. A. U. Zaman, J. Clean. Prod. 124, 41 (2016)

2. G. Romano, A. Rapposelli, and L. Marrucci, Resour. Conserv. Recycl. 146, 256 (2019)

3. S. Mishra and K. Mohanty, Bioresour. Technol. 273, 177 (2019)

4. R. Alrefai, B. KY, and S. J, J. Fundam. Renew. Energy Appl. 07, (2017)

5. G. De Bhowmick, A. K. Sarmah, and R. Sen, Sci. Total Environ. 650, 2467 (2019)

6. O. Sahimaa, M. K. Mattinen, S. Koskela, M. Salo, J. Sorvari, T. Myllymaa, J. Huuhtanen, and J. Seppälä, Sustain. Prod. Consum. 10, 121 (2017)

7. Direktorat Jenderal Perkebunan, Statistik Perkebunan Indonesia 2018-2020 (Sekretariat Direktorat Jenderal Perkebunan, Direktorat Jenderal Perkebunan, Kementerian Pertanian, Jakarta, 2020)

8. D. Khatiwada, C. Palmén, and S. Silveira, Biofuels 1 (2018)

9. Badan Pusat Statistik, Provinsi Jambi Dalam Angka 2020 (BPS-Statistic of Jambi Province, Jambi, 2020)

10. M. F. Awalludin, O. Sulaiman, R. Hashim, and W. N. A. W. Nadhari, Renew. Sustain. Energy Rev. 50, 1469 (2015)

11. K. E. Anyaoha, R. Sakrabani, K. Patchigolla, and A. M. Mouazen, Resour. Conserv. Recycl. 136, 399 (2018)

12. I. Rizkya, K. Syahputri, R. M. Sari, and D. S. Situmorang, IOP Conf. Ser. Mater. Sci. Eng. 851, (2020)

13. M. P. Kurniawan, A. D. Guritno, B. Purwantana, and W. Supartono, in IOP Conf. Ser. Earth Environ. Sci. (2020), p. 012042

14. R. Kramanandita, T. Bantacut, M. Romli, and M. Makmoen, Chem. Mater. Res. 6, $46(2014)$ 
15. E. Hambali and M. Rivai, IOP Conf. Ser. Earth Environ. Sci. 65, (2017)

16. I. Azman, Oil Palm Ind. Econ. J. 14, 34 (2014)

17. S. Z. Y. Foong, V. Andiappan, R. Tan, and D. K. S. Ng, MATEC Web Conf. 268, 02006 (2019)

18. N. Abdullah and F. Sulaiman, Biomass Now - Sustain. Growth Use 75 (2013)

19. R. Sindhu, P. Binod, A. Pandey, S. Ankaram, Y. Duan, and M. K. Awasthi, Biofuel Production from Biomass: Toward Sustainable Development (Elsevier B.V., 2019)

20. S. H. Chang, Biomass and Bioenergy 62, 174 (2014)

21. T. E. Omoniyi, AgriEngineering 1, 153 (2019)

22. R. A. Bakar, S. Z. Darus, S. Kulaseharan, and N. Jamaluddin, Nutr. Cycl. Agroecosystems 89, 341 (2011)

23. A. Moradi, C. Teh Boon Sung, K. J. Goh, A. Husni Mohd Hanif, and C. Fauziah Ishak, Soil Tillage Res. 145, 62 (2015)

24. L. S. Woittiez, S. R. I. Turhina, D. Deccy, M. Slingerland, M. Van Noordwijk, and K. E. N. E. Giller, Exp. Agric. 55, 543 (2019)

25. L. Qiao, D. Liu, X. Yuan, Q. Wang, and Q. Ma, Sustain. 12, (2020)

26. A. Karpušenkaitè, G. Denafas, and T. Ruzgas, Moksl. - Liet. Ateitis 8, 357 (2016)

27. J. Navarro-Esbrí, E. Diamadopoulos, and D. Ginestar, Resour. Conserv. Recycl. 35, 201 (2002)

28. F. Marandi and S. M. T. F. Ghomi, Proc. 12th Int. Conf. Ind. Eng. ICIE 201614 (2016)

29. A. Coghlan, 75 (2013)

30. H. Stichnothe and F. Schuchardt, Int. J. Life Cycle Assess. 15, 907 (2010)

31. H. H. Tao, J. L. Snaddon, E. M. Slade, L. Henneron, J. P. Caliman, and K. J. Willis, Agric. Ecosyst. Environ. 256, 105 (2018)

32. G. F. Chung, in Palm Oil Prod. Process. Charact. Uses (AOCS Press, 2012), pp. $163-210$ 